\title{
The impact of informalisation:
}

\section{Early agreements and voting cohesion in the European Parliament}

\section{Edoardo Bressanelli}

King's College London, London, UK

Christel Koop

King's College London, London, UK

Christine Reh

University College London, London, UK

\begin{abstract}
EU legislative decision-making is increasingly shifted into informal secluded arenas. Scholars have explained this trend and analysed its consequences for bargaining success and democratic legitimacy. Yet, we know little about how informalisation affects legislative behaviour in the EP. This article contributes to closing the gap, by theorising and analysing the impact of 'early agreements' on cohesion. Given the reputational, political and transaction costs of failing an early agreement in plenary, we expect political groups to invest heavily in discipline and consensus, and legislators to comply in votes. Using a new dataset, combining Hix et al.'s roll-call data with original codecision data (1999-2011), we show that informalisation increases cohesion but only for centrist parties. Rapporteurships and votes on 'costly' legislative resolutions also matter, but do not mediate the effect of early agreement.
\end{abstract}

\section{Keywords}

Cohesion, early agreements, European Parliament, ordinary legislative procedure, political groups.

\section{Corresponding author:}

Edoardo Bressanelli, King's College London, Department of European and International Studies, 22 Kingsway, London WC2B 6NR, UK. Email: edoardo.bressanelli@ kcl.ac.uk.

The authors would like to acknowledge their equal contribution.

Note:

This is the version of the article accepted for publication in European Union Politics.

DOI: $10.1177 / 1465116515608704$. 


\section{Introduction}

Over the last two decades, the European Parliament (EP) has been empowered to genuine colegislator, shared budgetary authority and prominent player in executive appointment (Hix and Høyland, 2013; Rittberger, 2006). In parallel, the codecision procedure was extended; introduced in 1993, it became the 'ordinary legislative procedure' in the Lisbon Treaty. Bicameral bargaining between the EP and the Council of Ministers is, therefore, key to explaining the EU's decision-making, policy-outputs and democratic governance. Since the late 1990s, bicameral bargaining has itself been transformed through its systematic shift from public inclusive to informal secluded arenas (Rasmussen, 2011; Reh et al., 2013). Expecting the increasing importance and informalisation of inter-institutional relations to affect political actors' internal organisation and legislative behaviour (Naurin and Rasmussen, 2011), our article assesses the impact of informal politics on parties' cohesion in the EP.

The informalisation of codecision results from the routine adoption of legislation at first (or early second) reading. Possible since 1999, first reading agreements soared from $28 \%$ in EP5 to $85 \%$ in EP7 (European Parliament, 2014:8). Early conclusion hinges upon the mere formalisation—or 'rubberstamping'—of a pre-agreed compromise; absent a priori consensus, this compromise is negotiated by representatives of the Council, EP and European Commission in informal secluded 'trilogues' before the file's first (or early second) reading.

In delivering votes - and, hence, majorities - on EU legislation, political groups play a crucial role. We theorise that the routine use of 'fast-track legislation' impacts on both party groups' and individual legislators' behaviour, by changing the costs and benefits associated with defection in plenary votes. Given the reputational, political and transaction costs of 
failing an informal compromise, we expect policy-seeking parties to invest particularly heavily in group 'discipline' and intra-party consensus, and we expect individual legislators to be particularly compliant with instructions when voting on 'early agreements' (EAs). As a consequence, cohesion should be higher when an informal compromise is tabled for formalisation in plenary. We test our hypotheses on a new dataset, complementing established data of roll-call votes since 1979 (Hix et al., 2007) with original data on all legislative files concluded under codecision between 1999 and 2011.

Our article aims to make three contributions to the literature on EU legislative politics. First, recent studies have explained the reasons for informalisation (Rasmussen, 2011; Reh et al., 2013), investigated its consequences for bargaining success (Farrell and Héritier, 2004; Rasmussen and Reh, 2013), and evaluated the democratic repercussions (Lord, 2013; Reh, 2014). Yet, we still know little about the impact of informalisation on intra-institutional politics and legislative behaviour (for exceptions, see Costello and Thomson, 2011; Yordanova, 2013:85-112). Second, scholars have offered several theoretical explanations for voting cohesion in the EP, ranging from legislators' (perceived) preference coherence to the growing effectiveness of supranational party organisation (see in particular Hix et al., 2007; Kreppel, 2002; Ringe, 2010). We assume that policy-seeking 'Europarties' had to adapt to the new inter-institutional game of codecision, and we argue that the routine use, specific nature and high stakes of informal bargaining create particularly favourable conditions for those mechanisms that lead to cohesion according to extant theories on party organisation. Third, cohesion has been welcomed as contributing to (supranational) democracy; by voting cohesively, parties deliver on their electoral agendas and contribute to managing societal cleavages (Hix et al., 2005, 2007:87; in general see Bowler et al., 1999a). Informalisation, by contrast, has been criticised as challenging accountability, transparency and public 
deliberation (Lord, 2013; in general see Bedock et al., 2012). A better theoretical and empirical understanding of whether and how informalisation affects cohesion-and, hence, the role of political parties in EU legislative politics - will, therefore, also allow a more nuanced normative evaluation of supranational decision-making.

Drawing from the literature on informal decision-making and legislative behaviour in the EP, we expect informalisation to contribute to cohesion. This general expectation is complemented with three conditional hypotheses on party centrism, institutional roles in bicameral bargaining, and types of plenary votes. We test our hypotheses using fractional logit models on a new dataset of political groups' roll-call votes in plenary on codecision files; for each of the EP's seven groups the dataset includes 494 roll-call votes for 424 files concluded between 1999 and 2011. We show that informalisation does increase cohesion, but only for the three centrist parties. This suggests that the European People's Party (EPP), the Party of European Socialists (PES) and the Alliance of Liberals and Democrats for Europe $(\mathrm{ALDE})^{1}$ invest more-and more successfully-in discipline, in coordination, or in both when their members vote on legislation pre-agreed in trilogue. However, we find no evidence for a conditional effect of legislative roles and types of plenary votes: rapporteurships and votes on 'costly' legislative resolutions matter, but they do not mediate the effect of EA.

\section{Early agreement, voting and cohesion: definitions and implications}

\section{The informal politics of codecision}

Following the EP's empowerment and the extension of codecision, bicameral bargaining has become key to EU decision-making; changing inter-institutional relations have affected intrainstitutional behaviour, organisation and politics (Naurin and Rasmussen, 2011). Yet, since 
the late 1990s, bicameral bargaining has not only become more important; it has also been transformed through informalisation and seclusion (Farrell and Héritier, 2004; Rasmussen, 2011; Reh et al., 2013).

Informalisation and seclusion result from the routine adoption of legislation at first or early second reading. Possible since 1999, first reading agreements have soared to $85 \%$ in EP7. As Figure 1 shows, even the sub-set of EAs which is not based on a priori agreement between the co-legislators but requires an informally negotiated compromise between Parliament and Council, has increased dramatically (Reh et al., 2013).

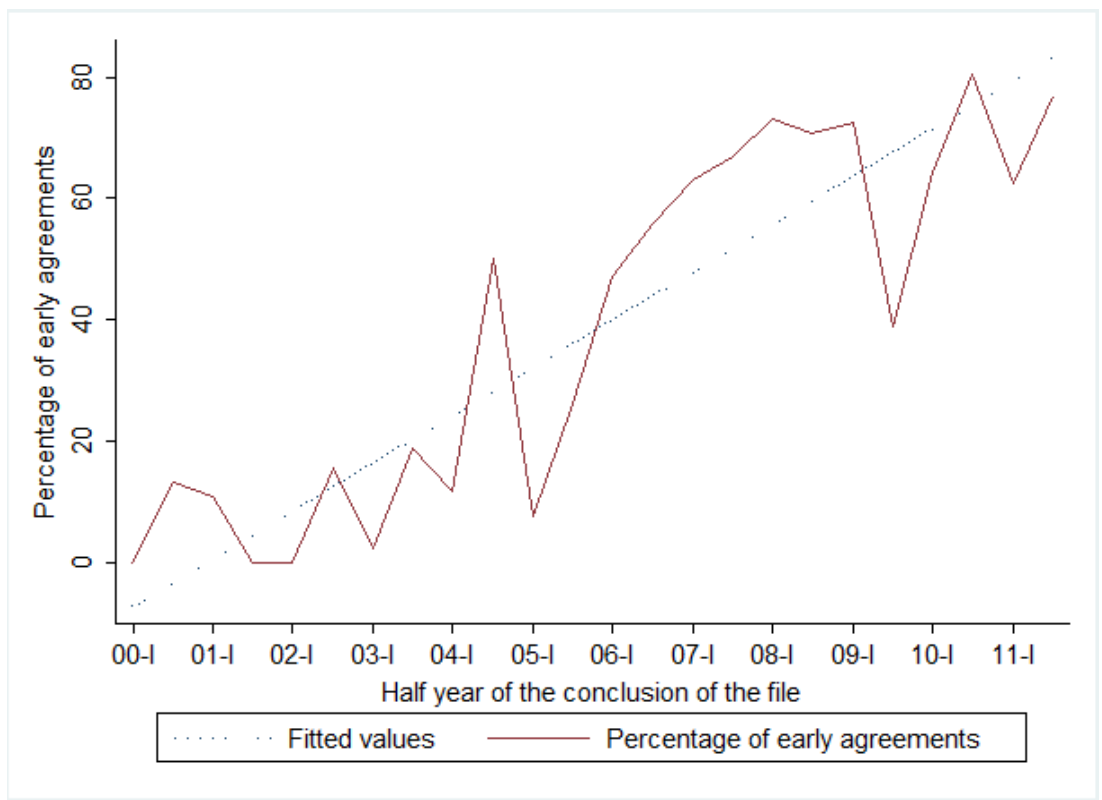

Figure 1. Percentage of EAs per half year (1999-2011).

The legislative compromise behind EAs is negotiated in informal trilogues, joining Council, Commission and Parliament representatives before the file's first or early second reading. ${ }^{2}$ Subsequently, the compromise is rubberstamped, officially confirmed in writing, and changes to the text, either in the EP's plenary (first reading) or a Council meeting (early second 
reading) 'can only be made [...] with the explicit agreement, at the appropriate level, of both institutions' (Corbett et al., 2011:243).

To conclude codecision at first reading, negotiations begin before the EP issues its formal opinion and before the Council adopts its common position. If the co-legislators agree informally, the EP incorporates, and accepts, the compromise in its own first reading amendments; it requires a simple majority to do so. Subsequently, the Council accepts the Commission proposal as amended by Parliament, with the procedure closed and the act adopted accordingly. To conclude an early second reading agreement, the EP, by simple majority, accepts - rather than amends - the Council's common position, which incorporates the inter-institutional deal. At this stage, the informal agreement is reached after the EP's first reading and before the Council's common position. The agreement is confirmed in a letter sent by the responsible committee chair to Council (Corbett et al., 2011:244).

In sum, under conditions of legislative conflict, an EA requires compromise negotiated in trilogue; trilogues are informal, secluded and restricted arenas of bicameral bargaining; and trilogue compromises are translated into EAs through rubberstamping by the Parliament's plenary and a Council meeting. These features directly impact on how Parliament and Council interact, and, therefore, on how political groups work at the early stages of codecision. First, opportunities for public debate and open contestation in plenary are reduced at first reading, while trilogues offer new opportunities for policy-influence. Second, negotiations between the parliamentary delegation and national governments start before the EP negotiates, votes and announces its first reading opinion; this compresses the search for compromise within political groups, between groups, and between co-legislators into one stage, dominated by restricted and secluded bargaining. Third, where informal agreement has 
been reached, parties in plenary no longer vote on the EP's amendments to the Commission proposal, but, instead, on the inter-institutional deal.

\section{Voting cohesion in the European Parliament}

To adopt legislation political groups must deliver majorities. However, the EP's transnational parties, should, a priori, face significant challenges in delivering these majorities cohesively.

First, the groups operate in an 'unusually complex' environment, characterised by a 'wealth of possible coalitions and salient dimensions of ideological conflict' (Hix et al., 2005: 210). In addition, the EP must approve-and can dismiss - the EU's 'executive', but the Commission does not depend on a parliamentary majority to govern, cannot tie a piece of legislation to a no-confidence vote, and cannot dissolve Parliament. Hence, the re-election prospects of a Member of the European Parliament (MEP) are not affected by her party's performance in government (Hix et al., 2005:211-13). Unlike in parliamentary systems, which 'fuse' the majority party (or coalition) in the legislature, and the party (or coalition) in government (see e.g. Bowler et al., 1999b), the EU's executive-legislative relations are not conducive to cohesion (Hix et al., 2005:211).

Second, while 'political affinities' are the pre-condition for forming a group, each must represent at least one-quarter of EU member states (European Parliament, 2015:Rule 32). Hence, groups are composed of national delegations, linked closely to domestic parties (Hix et al., 2005:210; Kreppel, 2002:177-211) and not necessarily ideologically homogenous (Bressanelli, 2012). Domestic parties nominate candidates for (re-)election, while national delegations are instrumental in allocating parliamentary office (Kreppel, 2002:202ff.). 
Accordingly, MEPs serve 'two principals' (Hix, 2002), and where preferences diverge legislators must trade off 'communicating' their position (by voting with their domestic party against the transnational party line) and 'deciding' (by delivering the transnational majority, even against their domestic party) (Hix et al., 2007:89f; for the general argument see Piketty, 2000). In national politics, legislators defy the whip to communicate to their constituency; in the EU's multi-level polity, legislators' trade-offs are triggered by the competing positions of their transnational and national parties (Hix et al., 2005:212).

These challenges notwithstanding, cohesion in the EP is very high. The analysis of roll-call votes in plenary at different periods between 1979 and 2010 shows legislators primarily voting 'along party lines rather than national lines' (Hix et al., 2007:88); this also holds true post-enlargement (Hix and Noury, 2009). Recent research on the EU's bicameral relations from 1999-2009 demonstrates that even when national ministers dissent in Council, MEPs from 'their' national delegations still mostly vote in line with their EP group (Mühlböck, 2013). Following the 2009 reform of the Rules of Procedure-making roll-calls mandatory for single and/or final legislative votes (European Parliament, 2015:Rule 179) — the absolute cohesion of the four biggest groups increased further, especially on final legislative votes (Yordanova and Mühlböck, 2015).

\section{Early agreement and voting cohesion: theorising the link}

\section{Explaining cohesion: extant theories}

Two groups of theoretical explanations-emphasising legislators' shared preferences and party organisation respectively-have addressed the 'puzzle of cohesion' in the EP. We introduce each in turn, before theorising the consequences of informal bicameral bargaining 
for legislative behaviour, in particular for groups' incentive structures and organisational consolidation, and for legislators' trade-offs.

The first established explanation focuses on shared preferences: where a party is ideologically homogenous, it is more likely to hold the line in a vote (Krehbiel, 1993). Kreppel (2002:208) has made this case for the EP, arguing that MEPs vote cohesively because they share beliefs and ideas, not because they fear punishment. McElroy and Benoit (2010) show that national parties join the EP's political groups based on 'policy congruence'; formed - by and large — by like-minded members, the groups then vote cohesively. Closely related, but focused on the strategic motivation for joining a party initially, scholars argue that legislators form parties to ensure collective policy-gains which cannot be secured individually, and to reduce the transaction costs of coalition-building (Hix et al., 2007:89). Cohesion is, accordingly, an expression of rational behaviour.

A second set of explanations centres on effective party organisation, maximising voting unity through two mechanisms: discipline and intra-party coordination. First, the leadership rewards and sanctions selectively and successfully. Cohesion, accordingly, stems from discipline (Bowler et al., 1999b) rather than shared preferences; it may be high even when parties are ideologically diverse, because this is the very moment to use carrots and sticks. The EP's group leaders do not nominate parliamentary candidates, but they control a range of offices and benefits: membership in committees, sub-committees and delegations, chairmanships, positions in the parliamentary and group hierarchy, rapporteurships and speaking time (Kreppel, 2002:198ff.). Analysing the EP between 1979 and 2004, Hix et al. (2007:101-102) see ideological diversity 'successfully buffered by the discipline of the transnational party organisations'. 
Yet, such an investment need not—and sometimes cannot — take the form of rewards and sanctions only. The EP's groups have 'fewer effective sanctions [...] than are usually available in national parliaments' (Corbett et al., 2011:121), with 'disciplining power' vested more in national delegations than in transnational leadership (Kreppel, 2002:202ff.). Given these limitations, parties additionally rely on institutionalised internal coordination. On the one hand, the party line can be created bottom-up through 'perceived preference coherence' (Ringe, 2010); in this process rank-and-file MEPs not directly involved in legislative negotiation take their 'voting cues' from 'experts' in their political groups.

However, when members outside the negotiation team have well-defined and potentially divergent preferences, groups face real risks of defection. In such cases-e.g. when MEPs in committee anticipate intra-party conflict in plenary, or when committee negotiations receive outside attention - parties will actively engage with their members (Roger and Winzen, 2015:394-95). Specific organisational structures-horizontal working groups, linking policyconnected committees-have been set up by the largest groups to mediate internal disagreement, reduce the risk of defection, and avoid a loss of influence and reputation (Bressanelli, 2014; Roger and Winzen, 2015; see Thierse, forthcoming, for how contestation and cohesion in committees affect groups' requests for roll-call votes in plenary).

\section{Does informalisation affect cohesion?}

Our theoretical argument is based on three assumptions. First, given the weak electoral connection between Europarties and the electorate, the EP's groups are policy- rather than vote-seeking, and parties and legislators know that their influence is higher as (part of) a group (Hix et al., 2007:32-53). Second, transnational parties' choices on how to invest their 
resources, and legislators' choices on whether to communicate or to decide, will depend on the perceived costs and benefits of defection. Third, these collective and individual costcalculations will be driven by the perceived possibility of policy-influence, and by the 'stakes' attached to a legislative vote (Hix et al., 2007:132-146; Kreppel, 2002:177-211).

Building on established explanations of cohesion, we propose that the key role of bicameral bargaining, the routine use and specific institutional set-up of informal trilogues, as well as the high stakes of EA votes change the perceived risks of defection in plenary; they, therefore, impact on the legislative behaviour of policy-seeking parties and MEPs; and this impact works through strengthening the organisational mechanisms behind cohesion. Given the policy-gains of co-decided legislation as well as the reputational, political and transaction costs associated with failing an informal pre-agreement, party elites will invest particularly heavily in discipline and coordination, and MEPs will be particularly willing to comply when voting on EAs. In short, informalisation should contribute to cohesion. However, we expect party properties, institutional roles, and types of votes to nuance the individual and collective risks of failing an EA in plenary, and we expect strategic calculations to vary accordingly.

Turning to reputational costs first, codecision trilogues are characterised by repeated and dense social interaction between EP and Council negotiators. Any agreement reached in trilogue is confirmed in writing, and each institution commits to rubberstamping if the other side honours the deal. The premium put on credibility and diffuse reciprocity in such a context (Axelrod, 1984) should, in turn, affect legislative behaviour. Most generally, successfully negotiating and reliably delivering informal compromise proves the Parliament's credibility, vis-a-vis the Council and the electorate. In addition, parties know that only if they deliver the votes and are willing to defend the outcome publicly, will the Council do the same 
in future negotiations. Similarly, only if rank-and-file MEPs support the compromise by following their parties, will their fellow group members support them, should they hold a rapporteurship or prominent committee position in future.

Second, defection makes the failure of an EA more likely, which comes at specific short-term and long-term political costs for groups and for their members. Short-term, the costs of coalition-building increase at 'normal' second reading, requiring absolute majority (Hagemann and Høyland, 2010). Long-term, non-adoption makes the use of trilogues less likely, thus risking this new opportunity for policy-seeking parties to influence the legislative agenda and outputs, and for individual legislators to capitalise on the key role 'relais actors' play at first reading (Farrell and Héritier, 2004).

Finally, when negotiating an EA, political groups incur transaction costs: of information gathering, the search for intra- and inter-party consensus, and the staffing of trilogues. Once these costs have sunk, and once an informal compromise has been found, groups will not want to risk failure in plenary. We, therefore, expect the party leadership to invest particularly heavily in the disciplining of, and negotiations with, divergent membersincreasing these MEPs' costs of defection in turn. The restriction and seclusion of trilogues further aggravate information asymmetries between rank-and-file MEPs and relais actors, making MEPs not involved in bicameral bargaining particularly dependent on voting cues.

In sum, the importance and informalisation of bicameral bargaining create favourable conditions for cohesion. Votes on EAs come with high stakes; where an informal compromise fails in plenary, parties risk losing reputation and credibility, institutional opportunities for influence, minimum-connected coalitions, and invested resources. 
Considering these stakes, groups should invest particularly heavily in discipline, in coordination, or in both. Informalisation, concomitantly, increases individual legislators' costs of defection-given their leadership's concentrated carrots, sticks and coordination; awareness of their own future dependence on diffuse reciprocity; the risk entailed in jeopardising new routes to policy-influence; and the challenge of overcoming information asymmetries at first reading. We therefore submit:

H1: Parties will be more cohesive when voting on an EA.

However, the costs of defection should vary with party properties, role and type of vote.

First, the EP's three centrist groups-defined as those being at the 'core' of the European party system (Smith, 1989) — and their MEPs incur particularly high costs from an EA's nonadoption. Given their roles within Parliament and vis-a-vis Council, the EPP, the PES and the ALDE in particular need to signal credibility; face high political costs when a file goes to second reading; and invest most resources in trilogues. All three centrists will always have 'counterparts' from their party families in the Council; ${ }^{3}$ the EPP, the PES or both will always be part of the majority coalition, while the Liberals are often pivotal to minimum-connected coalitions or part of 'super grand' alliances (Hix and Høyland, 2013); ${ }^{4}$ and the two biggest parties have the clout and the resources to be represented in all trilogues. This combination makes the centrists particularly dependent on diffuse reciprocity: only if they routinely deliver will their coalition partner(s) in both Parliament and Council do the same, and will they be able to capitalise on trilogues as novel arenas for policy-influence in the future. Individual MEPs, in turn, will not only be subject to more concentrated carrots, sticks and coordination; they may, simply, face less pressure to defect if their 'second principal'-the 
domestic party in Council—negotiates in trilogue and supports the deal.

Indeed, Hix et al. (2007:98, 102) found that a higher percentage of MEPs from parties in national government increases a group's cohesiveness. Their explanation-once the Council has found a compromise, domestic parties will pressure MEPs to adopt the legislationshould hold even more when the EP's groups are, themselves, party to the informal deal. This is most obvious when MEPs belong to centrist parties in government but, given the long 'shadow of the future' (Axelrod, 1984) cast by the routine use of fast-track legislation, and given its specific opportunities for policy-influence and bicameral cooperation, we expect the argument to also hold for MEPs from centrist parties in opposition. We therefore submit:

H2: EAs will have a particularly strong impact on the cohesion of centrist groups.

Second, the failure of an EA in plenary carries particular risks for the rapporteur and their party. Both incur high costs when negotiating an EA: bidding for a report is expensive; trilogues are resource-intensive; and rapporteurs are the most visible compromise brokers inside their parties, between groups, and in the bicameral arena (Costello and Thomson, 2010; Farrell and Héritier, 2004; Yordanova, 2011). For small parties, reports are particularly valuable; they are allocated few points and therefore 'own' few reports, each offering them a valued opportunity for influence. Big parties, in turn, need credible and constructive working relations with the Council, because they hold rapporteurships frequently. All parties also know that both the rapporteur's role and the required majority changes at second reading. These stakes will increase the report-owning party's investment in resources. MEPs, in turn, will not only face concentrated disciplining and coordination; they know that they, too, will depend on diffuse reciprocity once they own a report, and they will, therefore, be more 
willing to support 'their' rapporteur (Farrell and Héritier, 2003:588; see also Shackleton, 2000). We therefore submit:

H3: EAs will have a particularly strong impact on the cohesion of the rapporteur's group.

Finally, we expect parties' resource investment to vary with the stakes in a vote. Once a file reaches plenary via the EP's lead committee, MEPs can vote separately on the Commission's amended legislative proposal as a whole, and on the formalistic draft legislative resolution (European Parliament, 2015:Rule 59.2); only the vote on the latter formally concludes the first reading stage. In plenary votes on a potential EA, defection on the amended legislative proposal is, therefore, less damaging to credibility and less risky to an EA's adoption than defection on the draft legislative resolution. Furthermore, given the EA's 'rubberstamping requirement', the vote on the amended Commission proposal may be a group's only opportunity to engage in public political confrontation; where codecision runs to two or three stages, the EP's first reading affords such an opportunity. If party elites want to allow MEPs - potentially facing a trade-off between their two party principals - at least one possibility to protest and communicate, the vote on the amended Commission proposal offers a relatively risk-free opportunity to do so. We therefore submit:

H4: EAs will have a stronger impact on cohesion for votes on the legislative resolution than for votes on the amended Commission proposal. 


\section{Data and measurement}

Our hypotheses are tested on a new dataset of political groups' roll-call votes in plenary on codecision files. As first reading agreement became formally possible in 1999, we included codecision files concluded between July 1999 and December 2011; that is, in EP5, EP6 and the first half of EP7 (EP7-I). We incorporated all roll-call votes on the whole text, including votes on the amended Commission proposal (at first reading) and on the draft legislative resolution. ${ }^{5}$ Roll-call data are available for 424 of the 935 codecision files concluded in our time period (45\%). Roll-call data are unevenly distributed. Roll-calls became mandatory for final legislative votes in 2009; hence, our dataset includes roll-call data on all 138 files concluded in EP7-I, but only on 286 of the 797 files of EP5 and EP6 (36\%).

Assessing legislative behaviour with roll-calls has been criticised, because roll-calls are only one voting method in the EP (the others being 'show of hands' and electronic voting). As roll-calls have to be requested by a political group or at least 40 MEPs, they are not a representative sample of the population of all votes (e.g. Carrubba et al., 2006). However, only roll-calls show us how individual MEPs voted. In the EP, the proportion of roll-calls has increased over time (Hix and Høyland, 2013:182), and all groups can request them, making it 'difficult for any one party to restrict roll-calls to issues where they can enforce cohesion' (idem). Furthermore, the comparison of roll-calls in plenary before and after the 2009 reform-making roll-calls mandatory for single and/or final votes-demonstrates that cohesion has probably been under- rather than over-estimated (Yordanova and Mühlböck, 2015; but see Hug, forthcoming). Post-2009, the bias disappears for final legislative votes. 
Each codecision file can provide roll-call data on up to four votes on the whole text: two at first reading and one at both second and third reading. In practice, no procedure gives us data on four votes. For 356 of the 424 files there was only one roll-call. In almost all cases, this vote took place at first reading, where the first reading may or may not be the final reading. There are 66 files with two roll-calls. Most have votes on the amended proposal and the legislative resolution at first reading; some have two votes on legislative resolutions. There are two files with three roll-calls; both have votes on the amended proposal and legislative resolution at first reading and a vote at third reading. In total, we included data on 494 rollcall votes for 424 codecision files: 466 votes at first reading, six at second reading, and 22 at third reading. Among the first reading votes are 'single votes'; adopted in committee with less than one tenth of members opposed, these are not amended or debated (see Table 1).

Table 1. Type of roll-call vote and reading under codecision.

\begin{tabular}{l|cccc} 
& \multicolumn{4}{c}{ Type of vote } \\
& Amended proposal & Legislative resolution & Single vote & Total \\
\hline First reading & 66 & 315 & 85 & 466 \\
Second reading & & 6 & & 6 \\
Third reading & 66 & 22 & & 22 \\
\hline Total & & 343 & 85 & 494
\end{tabular}

For each of the 494 votes, we collected data on the seven political groups in EP7-I and their predecessors: (1) the EPP, (2) the PES, (3) the ALDE, (4) the Greens-European Free Alliance (G/EFA), (5) the European Conservatives and Reformists (Conservatives), (6) the European United Left-Nordic Green Left (GUE/NGL), and (7) Europe of Freedom and Democracy (Eurosceptics). As we are interested in intra-group dynamics, we do not consider the voting behaviour of non-attached MEPs. This leaves us with 3458 observations. 
Our dependent variable, intra-group cohesion, is captured with the agreement index (AI) proposed by Hix et al. (2005: 215): $A I_{i}=\left(\max \left\{Y_{i}, N_{i}, A_{i}\right\}-1 / 2\left[\left(Y_{i}+N_{i}+A_{i}\right)-\max \left\{Y_{i}, N_{i}, A_{i}\right\}\right]\right) /($ $Y_{i}+N_{i}+A_{i}$ ), where $Y_{i}$ refers to the number of 'yes' votes within group $i$ on a given vote, $N_{i}$ to the number of 'no' votes, and $A_{i}$ to the number of abstentions. The group's score equals 1 when all members vote together and 0 when they are equally divided between the three voting options. We used Hix et al. (2007) for roll-call data between 1999 and 2004 and VoteWatch for the period after 2004. Figure 2 presents the seven groups' average cohesion scores for the 494 roll-calls, including minimum and maximum scores. The scores are rather high but vary considerably with the PES, the ALDE, the G/EFA and the EPP at the top, followed by the Conservatives and GUE/NGL, and the Eurosceptics with the lowest average. The summary statistics for all variables are included in the online appendix.

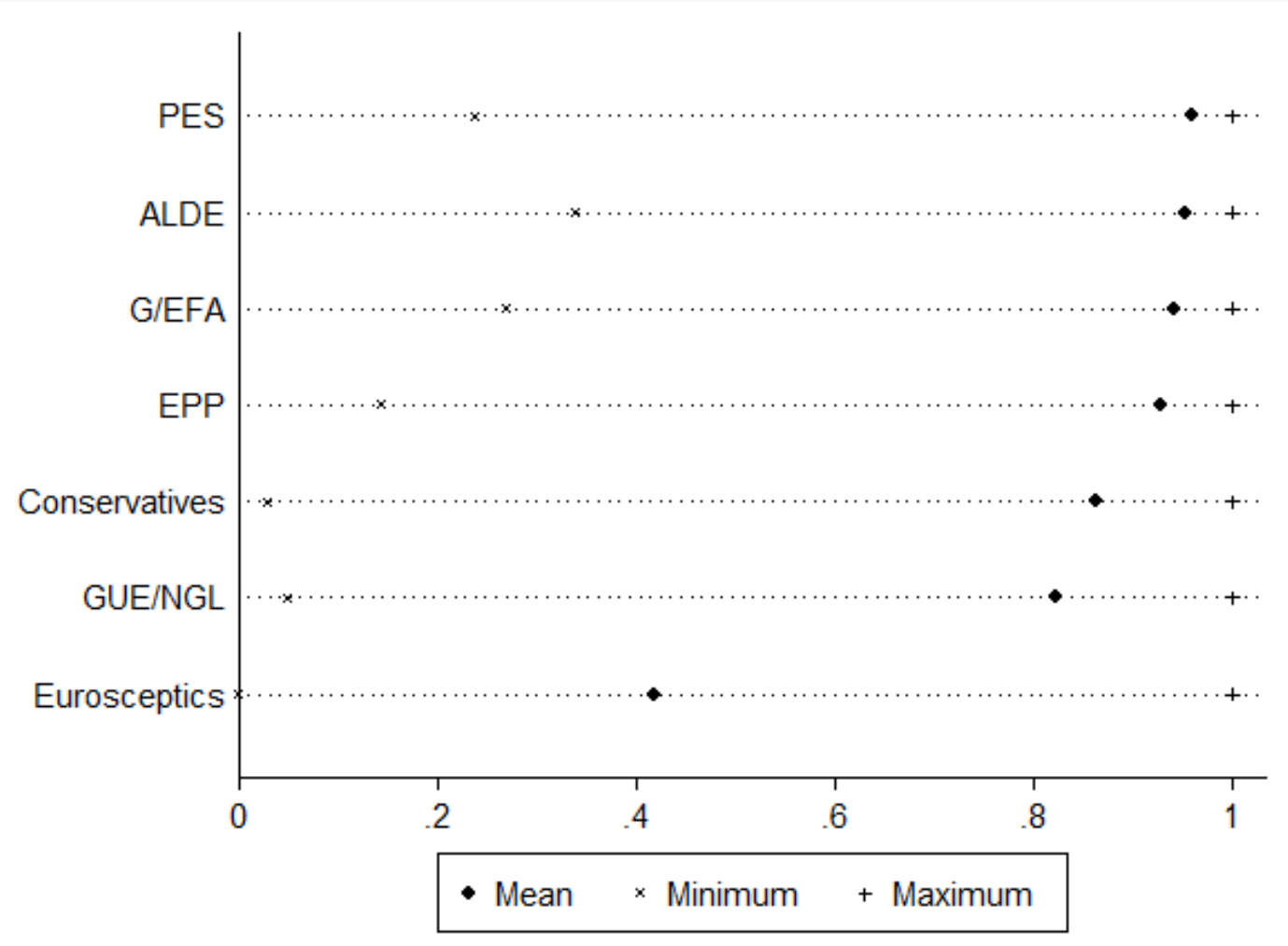

Figure 2. Cohesion by political group (mid-1999-2011). 
$H 1$ is tested with the dummy variable early agreement. This variable takes the value of 1 when the roll-call is held on a first or early second reading agreement and the text results from an informal inter-institutional compromise at first or early second reading; it is coded 0 for all other files (Reh et al., 2013:1127). There may be within-file variation: in the case of early second reading agreements, the vote on the same file at first reading is not coded as an EA, because the informal compromise was not yet struck. Of the 494 roll-calls in the dataset, 252 are EA votes (51\%); only five are based on early second reading agreements.

We have every reason to assume that the relationship between EA and cohesion runs in the hypothesised direction. As discussed in Section 2, the co-legislators agree informally before the plenary's (first reading) vote. Their deal is submitted to plenary either as part of the committee report, or as 'compromise amendments'; either way, the vote follows the informal agreement. Furthermore, EAs and cohesion are unlikely to be both driven by lacking contestation: uncontested codification files are not concluded as EAs, and neither a file's salience nor its redistributive consequences reduce the likelihood of early agreement (Reh et al., 2013). Indeed, files such as the 2009 Roaming Regulation, the 2009 Climate and Energy Package, and the 2011 'Six-Pack' on economic governance-all highly salient with redistributive elements—were EAs. By contrast, as shown below, salience reduces cohesion.

Three dummy variables assess our conditional hypotheses 2-4. First, centrism takes the value of 1 for votes of the EPP, the PES and the ALDE, and 0 for other groups' votes. Second, rapporteur takes the value of 1 when a group votes on a file for which it owns the report, and 0 when the rapporteur is from another group and for 'procedures without rapporteur'. Third, legislative resolution captures the type of vote, taking the value of 1 for votes on draft 
legislative resolutions and 0 for votes on amended Commission proposals. Single votes are, ultimately, votes on the draft legislative resolution and are subsumed under this category.

Our models include the following control variables. First, to capture potentially different behavioural dynamics in different parliaments and especially the 2009 rule-change, we included dummies for EP6 and EP7, with EP5 constituting the reference category. Second, codification procedures replace existing legislation without substantive changes; they are uncontested, a-political and dealt with by the legal services. We expect particularly high cohesion on these files. Third, cohesion should vary with salience. Salience is typically a consequence of high national or sectoral stakes and/or a file's strong symbolic value, and we expect MEPs to communicate and, hence, to defect more frequently on such files. We operationalised salience by measuring media attention in newspapers in four main languages and six member states, for the period between the Commission proposal and the act's adoption (see Reh et al., 2013:1128); to facilitate interpretation, the scores have been divided by ten. This measure is more exogenous to the legislative process than measures used previously (e.g. MEPs' participation in plenary votes or the number of roll-call votes in a particular period; Hix et al., 2007:123, 95). Fourth, as previous studies suggest that ideology affects voting (Hix and Høyland, 2013), ideologically diverse groups should be less cohesive. Using Euromanifesto data (Braun et al., 2009), we computed ideological diversity as the standard deviation of the left-right position of the national member parties (weighted by their number of seats) at the beginning of each parliamentary term. Finally, as the Eurosceptics' cohesion score is so different from the other parties', we include a control for that group. 


\section{Analysis}

As our dependent variable cohesion is continuous and bounded between 0 and 1 , the use of an OLS model is less appropriate. OLS estimates might fall outside its observed limits, leading to nonsensical predictions. Accordingly, we estimated fractional logit models, which are particularly useful for fractional response variables including zeros, ones, and intermediate values (Papke and Wooldridge, 1996; Yordanova and Mühlböck, 2015). As our data include seven observations per vote — one for each group — and, in some cases, more than one vote per procedure, we use clustered standard errors. More specifically, we clustered the errors (only) at the highest level —in our case, the procedure — which is the recommended strategy for nested two-way or multiway clustering (Cameron et al., 2011:238).

Table 2 reports the estimates of four models. Model 1 includes only the main effects, while Model 2 adds the interaction terms with early agreement and the other three variables. Model 3 incorporates the main effects, the interaction term with a significant effect in Model 2, and the control variables. Finally, Model 4 includes those variables that had a significant effect in the other models, and thus serves to assess the robustness of the findings. 
Table 2. The impact of early agreement on cohesion.

\begin{tabular}{|c|c|c|c|c|}
\hline & Model 1 & Model 2 & Model 3 & Model 4 \\
\hline & Coef (SE) & Coef (SE) & Coef (SE) & Coef (SE) \\
\hline Early agreement (EA) & $0.07(0.06)$ & $0.06(0.17)$ & $-0.02(0.09)$ & $0.00(0.07)$ \\
\hline Centrism & $1.60(0.10) * *$ & $1.25(0.12) * *$ & $0.54(0.12) * *$ & $0.52(0.11)^{* *}$ \\
\hline Centrism * EA & & $0.81(0.21) * *$ & $0.77(0.22) * *$ & $0.75(0.21) * *$ \\
\hline $\begin{array}{l}\text { Rapporteur } \\
\text { Rapporteur * EA }\end{array}$ & $0.59(0.13) * *$ & $\begin{array}{l}0.75(0.19) * * \\
-0.35(0.27)\end{array}$ & $0.37(0.12) * *$ & $0.38(0.12) * *$ \\
\hline $\begin{array}{l}\text { Legislative resolution } \\
\text { Resolution * EA }\end{array}$ & $0.36(0.07) * *$ & $\begin{array}{l}0.41(0.08) * * \\
-0.12(0.16)\end{array}$ & $0.38(0.08) * *$ & $0.38(0.09) * *$ \\
\hline EP6 & & & $0.01(0.14)$ & \\
\hline EP7 & & & $-0.03(0.15)$ & \\
\hline Codification & & & $0.57(0.09) * *$ & $0.59(0.08) * *$ \\
\hline Salience & & & $-0.02(0.01) * *$ & $-0.02(0.01) * *$ \\
\hline Ideological diversity & & & $-0.01(0.01)$ & \\
\hline Eurosceptics & & & $-2.28(0.07) * *$ & $-2.29(0.07) * *$ \\
\hline Constant & $0.79(0.07) * *$ & $0.82(0.08) * *$ & $1.74(0.18) * *$ & $1.60(0.10) * *$ \\
\hline $\mathrm{N}$ & 3458 & 3458 & 3458 & 3458 \\
\hline Log-pseudolikelihood & -1128.42 & -1123.82 & -928.46 & -928.84 \\
\hline
\end{tabular}

Note: Generalised linear model with a logit link function; standard errors are clustered by procedure.

$* * \mathrm{p}<0.01 ; * \mathrm{p}<0.05$

In a nutshell, the effect of the interaction centrism*early agreement is significant and in the expected direction. However, we do not find a more general effect of early agreement, and of early agreement conditional on rapporteur and legislative resolution. All main effects are positive and significant. Among our controls, codification has a significant, positive effect. Interestingly, salience is associated with a small, but significant, decline in cohesion. Neither ideological diversity nor the legislative term in which the vote took place seem to matter. ${ }^{6}$ The cohesion of the Eurosceptics is significantly lower than that of the other groups, in line with the descriptive statistics presented in Figure 2.

Turning to $H 1$ more specifically, EAs do not seem to increase cohesion. In Model 1, where the effect of early agreement is not conditional on other variables, its effect is positive but not 
significant. ${ }^{7}$ Second, the interaction centrism $*$ early agreement has a consistently significant, strong and positive effect on cohesion (Models 2-4). The models, therefore, show that the effect of informalisation is driven by the centrists (EPP, PES and ALDE). Not only are these groups more cohesive than the others (with the G/EFA exception); they are particularly cohesive when MEPs vote on legislation pre-agreed informally. This finding strongly supports $H 2$. The effect is more clearly illustrated by Figure 3, which presents the predicted cohesion scores for votes on EAs as opposed to 'normal' votes, distinguishing between centrists and non-centrists. Following Brambor et al. (2006:75ff.), we present the predicted cohesion scores at each level of our independent variables together with confidence intervals.

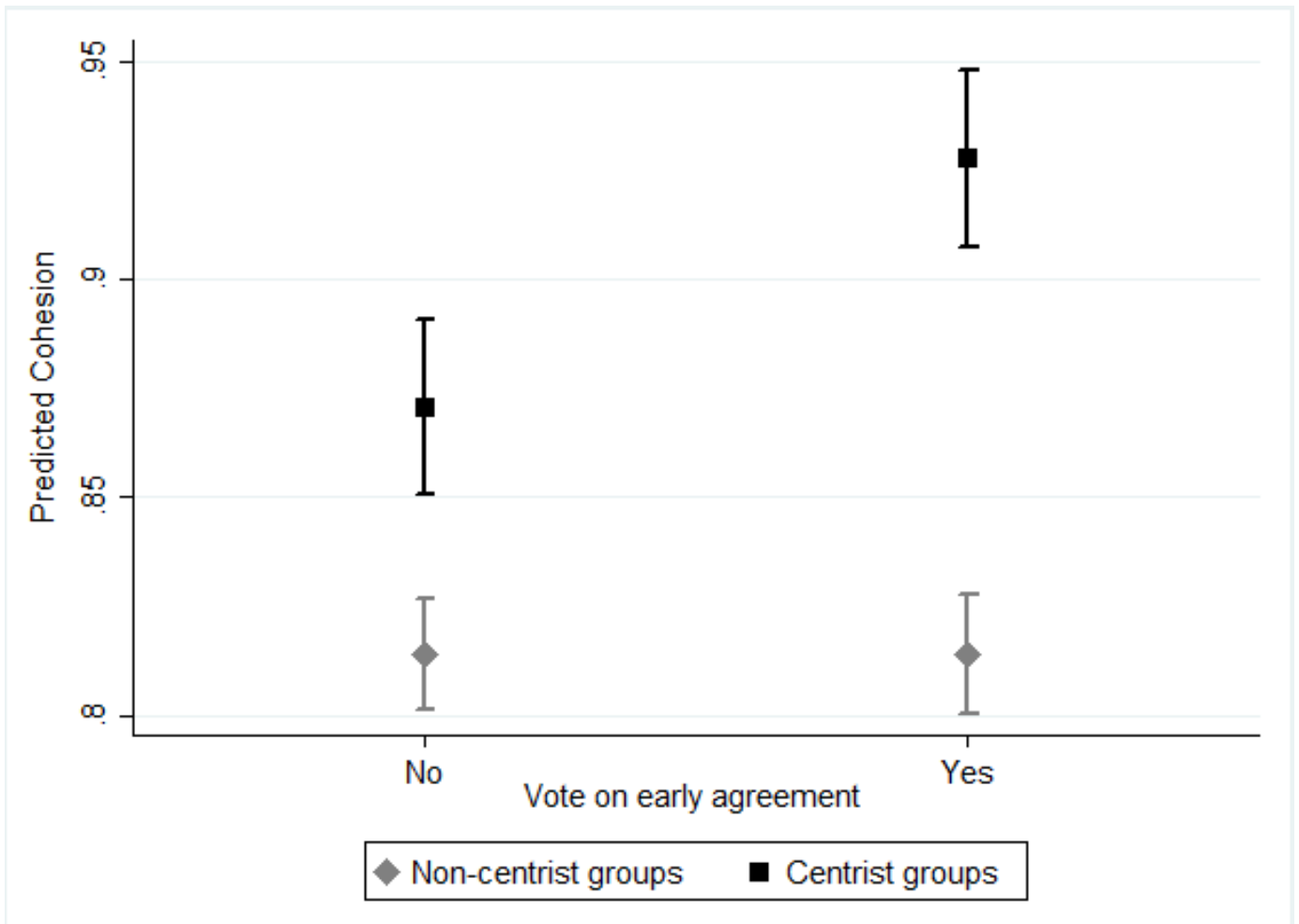

Figure 3. The effect of centrism and early agreement on cohesion (Model 4).

The figure clearly shows informalisation impacting differently on different types of groups. For the non-centrists, the predicted cohesion scores for EAs and normal files are very similar (at about $83 \%$ ), and the confidence intervals overlap almost completely. Yet, when the 
centrists vote on EAs, their predicted cohesion score increases by almost 6 percentage points, with no overlap at all between the confidence intervals. This finding is important, given our argument about the differential impact of informal inter-institutional relations and, therefore, cost-calculations across types of political groups and their members.

To understand this variation better, Table 3 presents the analysis per political group. The models include the main effects of interest-early agreement, rapporteur and legislative resolution - and the control variables that had a significant effect in Table 2 . EA does, indeed, impact differently on different groups: cohesion is significantly higher on EAs for the EPP, the PES and the ALDE; there is no significant difference in the cases of the G/EFA, the GUE/NGL and the Conservatives; and the Eurosceptics are even less cohesive when voting on EAs, though the effect is not significant. ${ }^{8}$ Looking at the relevant variables, the three centrist groups seem subject to similar behavioural dynamics: they are significantly more cohesive when voting on legislative resolutions, on codification files, and (except for the Liberals) when they 'own' the report. Salience, by contrast, affects cohesion negatively.

Interestingly, the cohesion of the G/EFA - the fourth largest group in the period under consideration - is increased by EA, but the effect is just below significance and less strong than for the centrists. This may be because the G/EFA is more often in opposition to the EPP and PES - both at the European and national level — than the ALDE. Facing lower reputational and political costs when an inter-institutional agreement fails in plenary, the G/EFA leadership may, accordingly, be less pressed to push its members to hold the line. Nonetheless, the effect of EA across groups declines gradually: the G/EFA figure is much closer to the centrists' ones than are those of the other non-centrist parties. 
Table 3. The impact of early agreement on cohesion, per group.

\begin{tabular}{|c|c|c|c|c|c|c|c|}
\hline & EPP & PES & ALDE & G/EFA & GUE/NGL & Conservatives & Eurosceptics \\
\hline & Coef (SE) & Coef (SE) & Coef (SE) & Coef (SE) & Coef (SE) & Coef (SE) & Coef (SE) \\
\hline Early agreement & $0.88(0.18) * *$ & $0.69(0.27)^{*}$ & $0.89(0.25)^{* *}$ & $0.31(0.17)$ & $0.02(0.12)$ & $0.11(0.15)$ & $-0.17(0.09)$ \\
\hline Rapporteur & $0.50(0.17) * *$ & $0.89(0.29)^{* *}$ & $-0.17(0.33)$ & $1.08(0.26)^{* *}$ & $0.40(0.26)$ & $0.49(0.43)$ & $-0.61(0.21)^{* *}$ \\
\hline Legislative resolution & $0.51(0.19)^{* *}$ & $0.91(0.28)^{* *}$ & $0.98(0.26)^{* *}$ & $0.66(0.24)^{* *}$ & $-0.01(0.17)$ & $0.78(0.18)^{* *}$ & $-0.09(0.13)$ \\
\hline Codification & $2.55(0.36)^{* *}$ & $2.93(0.53)^{* *}$ & $4.21(0.99)^{* *}$ & $0.58(0.31)$ & $2.99(0.64) * *$ & $0.99(0.24) * *$ & $-0.36(0.15)^{*}$ \\
\hline Salience & $-0.05(0.01)^{* *}$ & $-0.08(0.01)^{* *}$ & $-0.05(0.01)^{* *}$ & $0.02(0.02)$ & $0.04(0.01)^{* *}$ & $-0.04(0.01)^{* *}$ & $0.02(0.00)^{* *}$ \\
\hline Constant & $1.56(0.17)^{* *}$ & $1.90(0.24)^{* *}$ & $1.88(0.22)^{* *}$ & $2.01(0.24)^{* *}$ & $1.46(0.15)^{* *}$ & $1.10(0.17)^{* *}$ & $-0.16(0.12)$ \\
\hline $\mathrm{N}$ & 494 & 494 & 494 & 494 & 494 & 494 & 494 \\
\hline Log-pseudolikelihood & -96.96 & -65.82 & -71.18 & -86.25 & -175.35 & -154.07 & -241.23 \\
\hline
\end{tabular}

Note: Generalised linear model with a logit link function; robust standard errors.

$* * \mathrm{p}<0.01 ; * \mathrm{p}<0.05$ 
Our article set out to explore whether the informalisation of bicameral bargaining has consequences for parties' legislative behaviour. Our results suggest that partisan ties across chambers do 'matter' by constraining MEPs' voting behaviour. Negotiators from the EPP, the PES and the ALDE will most frequently join Council counterparts from their party families in informal trilogues, and their groups are also most cohesive when voting on EAs. For individual legislators, the mechanism of reaching EAs - collapsing previously sequential negotiation into one informal arena where national and transnational parties meet - may have a more fundamental consequence, namely to reduce the very trade-off at the heart of the cohesion puzzle: the tension between communicating and deciding. How exactly informal bicameral bargaining increases cohesion cannot be explored by our large- $\mathrm{N}$ research design. Yet, our results underscore that 'transnational parties act as a co-ordination mechanism reducing the transaction costs of bargaining' (Lindberg et al., 2008:1120).

By contrast, the analysis does not support $H 3$ and $H 4$. Holding the rapporteurship and voting on a legislative resolution does not mediate the effect of early agreement. ${ }^{9}$ Yet, the two variables' main effects are significant, positive and robust. Based on predictions from Model 4, holding the rapporteurship and voting on a legislative resolution make a group more cohesive by about 3 and 5 percentage points respectively (other things being equal). Both findings are important. The former underlines the relevance of institutional roles in bicameral bargaining; the latter indicates that groups behave strategically, leaving their members more freedom when voting on amended Commission proposals than on the high stakes draft legislative resolutions, irrespective of whether the file is agreed early or not.

A final comment is warranted for our controls. Votes on uncontested codification procedures are, unsurprisingly, significantly more cohesive. More importantly, salience has a significant and negative effect on cohesion. Hence, high (national) stakes, symbolic importance, rising 
public attention and greater interest group pressure seem to lead individual MEPs, or entire national delegations, to defect more from the transnational party line.

\section{Conclusions}

This article theorised and analysed the consequences of the EU's changing inter-institutional relations for parties' legislative behaviour. We argued that the growing importance of bicameral bargaining and its increasing informalisation contribute to political groups' organisational consolidation by changing the reputational, political and transaction costs of defection as perceived by policy-seeking parties and MEPs. We therefore suggested that informalisation increases cohesion. We expected groups to invest heavily in discipline and intra-party consensus, and individual members to be particularly compliant when voting on a potential EA. Given variation in perceived costs and, hence, strategic calculations, we hypothesised a particularly strong impact of informalisation on the centrist political groups, the rapporteur's group, and votes on the draft legislative resolution.

We tested our hypotheses using a dataset of 494 roll-call votes cast by MEPs in seven political groups on 424 codecision files concluded in EP5, EP6 and EP7-I. Cohesion is, indeed, higher on EA votes, but only for votes cast by the centrist groups: only the EPP, the PES and the ALDE vote considerably and significantly more cohesively on EAs. Informalisation, therefore, does not affect all political groups equally. This finding supports our theoretical argument on centrism. Interacting regularly and repeatedly with their domestic Council counterparts in trilogues, the EPP, the PES and the ALDE will invest more-and more successfully — in discipline, in coordination, or in both. We suggest that this is because EAs increase the perceived reputational and political costs of non-adoption, while lowering 
domestic pressures for individual MEPs to defect. Holding the rapporteurship also increases cohesion, but does not strengthen the effect of informalisation. Similarly, cohesion increases for the high stakes draft legislative resolutions, but does not mediate the effect of EA.

These findings have broader implications for the study of legislative behaviour in the EP. The informalisation of bicameral bargaining seems to strengthen the centrist political groups. Only follow-up qualitative research can uncover the exact causal mechanism behind this effect. We argued that repeated, informal and successful negotiation with the Council at the early stages of codecision gives the centrists greater leverage in averting defection should MEPs' national and transnational parties conflict. What more, given that pre-negotiations will frequently involve representatives from both national and transnational centrist parties, with pre-agreements committing both Council and Parliament, domestic parties themselves may be more likely to support EAs. In this case informalisation should reduce the potential conflict between the position of the Europarties and 'their' national parties, and, thereby, the MEPs' communication-decision trade-offs. Hence, the routine successful use of the informal arena may not only transform the institutional but also the political context in which parties decide how to invest in discipline and intra-party consensus, and in which MEPs choose whether to communicate or to decide.

Finally, our results raise broader normative concerns. The EP has developed into a highly specialised institution, where a restricted set of actors-(shadow) rapporteurs, coordinators, group leaders-strongly influence decision-making (Bailer et al., 2009; Jensen and Winzen, 2012). The EP is also a partisan institution, where the largest groups hold most organisational and decision-making power; they often side with each other in 'black-red' coalitions (Rose, 2013), frequently including the ALDE to become super grand (Hix and Høyland, 2013). In 
such a context, the routine pre-agreement of legislation in secluded arenas, dominated by cohesive super-majorities of the centrist Europarties not only within but across the EU's institutions, questions whether codecision has had the intended positive effect on public deliberation and inclusiveness (Lord, 2013), and whether the democratic benefits of cohesion found in other representative democracies can travel to the EU. To the contrary, the cohesion of the centrist groups may signal growing 'cartelisation', with the major parties capitalising on informal politics to gain both influence over policy and control over their members.

\section{Acknowledgements}

We would like to thank Lukas Obholzer and Marco Visentini Scarzanella for their valuable research assistance, and Sarah Blau for patiently answering our questions on codecision in practice. We are grateful to Christian Breunig, Philipp Broniecki, Christine Neuhold, Sebastiaan Princen and three anonymous referees for their excellent comments on earlier versions of this article. Our thanks also go to audiences at University College London and the University of Reading; at the ECPR-SGEU in The Hague (June 2014); EPSA in Edinburgh (June 2014); the conference 'Perspectives on European Governance in Comparative Perspective: Interests, Institutions and Policy-Making' in Berlin (July 2014); and the ECPR General Conference in Glasgow (September 2014). The paper has greatly benefited from our earlier cooperation with Adrienne Héritier. Finally, our thanks go to the late Peter Mair for encouraging us to think about the repercussions of informalisation for political parties.

\section{Funding}

Data collection for this paper was funded by the Economic and Social Research Council (Grant RES-000-22-3661), the European University Institute and University College London. 


\section{Notes}

1. The parliamentary EPP was labelled EPP-ED from 1999 to 2009. The parliamentary PES was relabelled Group of the Progressive Alliance of the Socialists and Democrats (S\&D) in 2009.

2. Trilogues also occur at later stages; in fact, they were 'invented' for conciliation (Shackleton, 2000). Yet, first and early second reading trilogues are best-suited to test the impact of informalisation and seclusion, because only at those stages do trilogues exemplify informal politics and does the adoption of legislation fully depend on secluded pre-agreement (see Reh et al., 2013:1115-20).

3. At the beginning of EP7, 17 national governments included EPP parties, 14 included PES parties, and ten included ALDE parties. Three governments included G/EFA or Conservative parties; only one a GUE/NGL party. In 2004, 14, 13 and ten national governments included EPP, PES and ALDE parties. At the time, only two governments included a G/EFA party and three a Conservative party. In 1999, 12 governments included at least one PES party, six an ALDE party, and five an EPP party. G/EFA or GUE/NGL parties participated in government in three countries (data from Döring and Manow, 2015).

4. In EP6 and EP7, grand coalitions and super grand coalitions (including the ALDE) formed in about $70 \%$ of all roll-call votes, while centre-left and centre-right alliances won in about $15 \%$ of the votes (Hix and Høyland, 2013:179). In codecision, the centrists were on the winning side in about $85 \%$ of the votes in EP6; the percentage was under 60 for the G/EFA and the GUE/NGL (VoteWatch, 2013:4). Furthermore, comparing all votes in the first half of EP7, the ALDE voted differently from the grand coalition about $6 \%$ of the time. This figure was $19 \%$ for the G/EFA and more than 25\% for the other groups (www.votewatch.eu).

5. The analysis is restricted to votes on the whole text, because the function of plenary amendments varies at first reading (Corbett et al., 2011:244). When the committee report submitted to plenary incorporates the inter-institutional deal, newly tabled amendments must be considered 'rogue'; when trilogues negotiate on the basis of the committee report, the inter-institutional deal is submitted to plenary in the form of 'compromise amendments'. Under EAs, amendments are therefore difficult to compare without retrieving information on each and every one of them, which is clearly beyond the scope of this project.

6. To further explore the time dimension, we estimated the models with two other specifications. First, we replaced EP6 with a linear time trend variable (cf. Hix et al., 2007:99), keeping in EP7 to capture the 2009 rule-change. This produced similar results. Second, following Lindstädt et al. (2011:59), we created a variable for the year within the legislative term to control for changes in cohesion over time within terms. Including both a linear and squared version of the variable did not produce any effect, and the other results stayed the same. 
7. In a bivariate model, early agreement is significant (at the $5 \%$ level), with a positive effect on cohesion (the coefficient is 0.10 ).

8. We note that among the centrist parties the effect of EAs is consistently significant for the EPP and the ALDE; in the case of the PES, the coefficient is always large and positive, but its significance is not fully robust to all additional model specifications we ran.

9. To check the robustness of this finding, we ran alternative models where the interaction terms are introduced one by one. As Table B in the online appendix shows, these analyses corroborate the finding that the effect of early agreement conditional on rapporteur and legislative resolution is not significant.

\section{References}

Axelrod R (1984) The Evolution of Cooperation. New York: Basic Books.

Bailer S, Schulz T and Selb P (2009) What role for the party group leader? A latent variable approach to leadership effects on party group cohesion in the European Parliament. Journal of Legislative Studies 15(4): 355-378.

Bedock C, Mair P and Wilson A (2012) Institutional change in advanced democracies: An exploratory assessment. EUI Working Paper RSCAS 2012/11. Florence: European University Institute. Available at http://cadmus.eui.eu/handle/1814/20817 (accessed on 14 August 2015).

Bowler S, Farrell DM and Katz RS (eds) (1999a) Party Discipline and Parliamentary Government. Columbus: Ohio State Press.

Bowler S, Farrell DM and Katz, RS (1999b) Party Cohesion, Party Discipline, and Parliaments. In: Bowler S, Farrell DM and Katz RS (eds) Party Discipline and Parliamentary Government. Columbus: Ohio State Press, pp. 3-22.

Brambor T, Clark WR and Golder M (2006) Understanding interaction models: Improving empirical analyses. Political Analysis 14(1): 63-82. 
Braun D, Mikhaylov S and Schmitt H (2010). EES (2009) Manifesto Study Documentation Advance Release (user beware/pre-release B). 22/07/2010. Available at www.piredeu.eu (accessed on 14 August 2015).

Bressanelli E (2012) National parties and group membership in the European Parliament: Ideology or pragmatism? Journal of European Public Policy 19(5): 737-754.

Bressanelli E (2014) Necessary deepening? How political groups in the European Parliament adapt to enlargement. Journal of European Public Policy 21(5): 776-792.

Cameron AC, Gelbach JB and Miller DL (2011) Robust inference with multiway clustering. Journal of Business \& Economic Statistics 29(2): 238-249.

Carrubba CJ, Gabel M, Murrah L, et al. (2006) Off the record: unrecorded legislative votes, selection bias, and roll-call vote analysis. British Journal of Political Science 36(4): 691-704.

Corbett R, Jacobs F and Shackleton M (2011) The European Parliament. $8^{\text {th }}$ ed. London: John Harper.

Costello R and Thomson R (2010) The policy impact of leadership in committees: Rapporteurs' influence on the European Parliament's opinions. European Union Politics 11(2): 219-240.

Costello R and Thomson R (2011) The nexus of bicameralism: Rapporteurs' impact on decision outcomes in the European Union. European Union Politics 12(3): 337-357.

Döring $\mathrm{H}$ and Manow P (2015) Parliaments and Governments Database (ParlGov): Information on Parties, Elections and Cabinets in Modern Democracies. Development version. Available at http://www.parlgov.org/static/static-2014/stable/index.html (accessed on 14 August 2015).

European Parliament (2014) Activity Report 14 July 2009 to 30 June 2014 (DV\1031024).

Brussels: $\quad$ European Available at 
http://www.europarl.europa.eu/code/about/activity_reports_en.htm (accessed on 14 August 2015).

European Parliament (2015). Rules of Procedure. $8^{\text {th }}$ Parliamentary Term. Brussels:

$\begin{array}{lll}\text { European } & \text { Parliament. Available at }\end{array}$ http://www.europarl.europa.eu/sides/getLastRules.do?reference=RULE-

$\underline{130 \& \text { language }=\mathrm{EN}}$ (accessed on 14 August 2015).

Farrell $\mathrm{H}$ and Héritier A (2003) Formal and informal institutions under codecision: Continuous constitution-building in Europe. Governance 16(4): 577-600.

Farrell H and Héritier A (2004) Interorganizational negotiation and intraorganizational power in shared decision-making. Comparative Political Studies 37(10): 1184-1212.

Hagemann S and Høyland B (2010) Bicameral politics in the European Union. Journal of Common Market Studies 48(4): 811-833.

Helmke G and Levitsky S (2004) Informal institutions and comparative politics: A research agenda. Perspectives on Politics 2(4): 725-740.

Hix S (2002) Parliamentary behavior with two principals: Preferences, parties, and voting in the European Parliament. American Journal of Political Science 46(3): 688-698.

Hix S, Noury A and Roland G. (2005) Power to the parties: Cohesion and competition in the European Parliament, 1979-2001. British Journal of Political Science 35(2): 209-234.

Hix S, Noury AG and Roland G (2007) Democratic Politics in the European Parliament. Cambridge: Cambridge University Press.

Hix S and Noury A (2009) After enlargement: Voting patterns in the Sixth European Parliament. Legislative Studies Quarterly 34(2): 159-174.

Hix S and Høyland B (2013) Empowerment of the European Parliament. Annual Review of Political Science 16: 171-189. 
Hug S (2016) Party pressure in the European Parliament. European Union Politics (forthcoming).

Jensen T and Winzen T (2012) Legislative negotiations in the European Parliament. European Union Politics 13(1): 118-1149.

Krehbiel K (1993) Where's the party? British Journal of Political Science 23(2): 235-266.

Kreppel A (2002) The European Parliament and Supranational Party System: A Study in Institutional Development. Cambridge: Cambridge University Press.

Lindberg B, Rasmussen A and Warntjen A (2008) Party politics as usual? The role of political parties in EU legislative decision-making. Journal of European Public Policy 15(8): 1107-1126.

Lindstädt R, Slapin JB and Vander Wielen RJ (2011) Balancing competing demands: Position taking and election proximity in the European Parliament. Legislative Studies Quarterly 36(1): 37-69.

Lord C (2013) The democratic legitimacy of codecision. Journal of European Public Policy 20(7): 1056-1073.

McElroy G and Benoit K (2010) Party policy and group affiliation in the European Parliament. British Journal of Political Science 40(2): 377-398.

Mühlböck M (2013) Linking Council and European Parliament? Voting unity of national parties in bicameral EU decision-making. Journal of European Public Policy 20(4): $571-588$.

Naurin D and Rasmussen, A (2011) New external rules, new internal games: How the EU institutions respond when inter-institutional rules change. West European Politics 34(1): 1-17. 
Papke LE and Wooldridge JM (1996) Econometric methods with fractional response variables with an application to 401(K) Plan Participation Rates. Journal of Applied Econometrics 11(6): 619-632.

Piketty T (2000) Voting as communicating. The Review of Economic Studies 67(1): 169-191.

Rasmussen A (2011) Early conclusion in bicameral bargaining: Evidence from the codecision legislative procedure of the European Union. European Union Politics 12(1): 41-64.

Rasmussen A and Reh C (2013) The consequences of concluding codecision early: Trilogues and intra-institutional bargaining success. Journal of European Public Policy 20(7): 1006-24.

Reh C (2014) Is informal politics undemocratic? Trilogues, early agreements and the Selection Model of Representation. Journal of European Public Policy 21(6): 822-841.

Reh C, Héritier A, Bressanelli E and Koop C (2013) The informal politics of legislation: Explaining secluded decision making in the European Union. Comparative Political Studies 46(9): 1112-1142.

Ringe N (2010) Who Decides, and How? Preferences, Uncertainty, and Policy Choice in the European Parliament. Oxford: Oxford University Press.

Rittberger B (2006) Building Europe's Parliament: Democratic Representation Beyond the Nation State. Oxford: Oxford University Press.

Roger L and Winzen T (2015) Party groups and committee negotiations in the European Parliament: Outside attention and the anticipation of plenary conflict. Journal of European Public Policy 22(3): 391-408.

Rose R (2013) Representing Europeans. A Pragmatic Approach. Oxford: Oxford University Press. 
Shackleton M (2000) The politics of codecision. Journal of Common Market Studies 38(2): $325-342$.

Smith G (1989) Core persistence: Change and the 'People's Party'. West European Politics 12(4): 157-168.

Thierse S (2016) Going on record: Revisiting the logic of roll-call vote requests in the European Parliament. European Union Politics (forthcoming).

VoteWatch (2013) 20 Years of Codecision. VoteWatch Europe Special Policy Brief. Available from: http://www.votewatch.eu/blog/wp-content/uploads/2013/12/votewatcheurope-special-policy-brief-20-years-of-co-decision_final.pdf (accessed on 14 August 2015).

Yordanova N (2011) Inter-institutional rules and the division of power in the European Parliament: Allocation of consultation and co-decision reports. West European Politics 34(1): 97-121.

Yordanova N (2013) Organizing the European Parliament. The Role of Committees and their Legislative Influence. Colchester: ECPR Press.

Yordanova N and Mühlböck M (2015) Tracing the selection bias in roll call votes: Party group cohesion in the European Parliament. European Political Science Review 7(3): 373-399. 
Online Appendix

Table A. Summary statistics.

\begin{tabular}{lccccc}
\hline & Mean & SD & Min & Max & N \\
\hline Cohesion & 0.84 & 0.24 & 0 & 1 & 3458 \\
Early agreement & 0.51 & 0.50 & 0 & 1 & 3458 \\
Centrism & 0.43 & 0.49 & 0 & 1 & 3458 \\
Rapporteur & 0.14 & 0.35 & 0 & 1 & 3458 \\
Legislative resolution & 0.87 & 0.34 & 0 & 1 & 3458 \\
EP6 & 0.53 & 0.50 & 0 & 1 & 3458 \\
EP7 & 0.27 & 0.44 & 0 & 1 & 3458 \\
Codification & 0.05 & 0.21 & 0 & 1 & 3458 \\
Salience & 0.33 & 2.97 & 0 & 46.45 & 3458 \\
Ideological diversity & 12.35 & 4.93 & 0.6 & 21.4 & 3458 \\
\hline
\end{tabular}

Table B. The impact of early agreement on cohesion, individual interaction terms.

\begin{tabular}{lll}
\hline & \multicolumn{1}{c}{ Model A1 } & \multicolumn{1}{c}{ Model A2 } \\
\hline & \multicolumn{1}{c}{ Coef (SE) } & \multicolumn{1}{c}{ Coef (SE) } \\
Early agreement (EA) & $0.14(0.10)$ & $0.25(0.23)$ \\
Centrism & $0.87(0.11)^{* *}$ & $0.87(0.11) * *$ \\
Centrism * EA & & \\
Rapporteur & $0.37(0.16)^{*}$ & $0.37(0.12) * *$ \\
Rapporteur * EA & $-0.00(0.23)$ & \\
Legislative resolution & $0.38(0.08)^{* *}$ & $0.43(0.09) * *$ \\
Resolution * EA & & $-0.14(0.20)$ \\
& & \\
EP6 & $0.01(0.14)$ & $0.02(0.14)$ \\
EP7 & $-0.00(0.16)$ & $-0.00(0.16)$ \\
Codification & $0.59(0.09)^{* *}$ & $0.58(0.09) * *$ \\
Salience & $-0.02(0.00) * *$ & $-0.02(0.00) * *$ \\
Ideological diversity & $-0.01(0.01)$ & $-0.01(0.01)$ \\
Eurosceptics & $-2.28(0.07) * *$ & $-2.28(0.07) * *$ \\
& & \\
Constant & $1.62(0.18) * *$ & $1.58(0.19) * *$ \\
$\mathrm{~N}$ & 3458 & 3458 \\
Log-pseudolikelihood & -932.58 & -932.48 \\
\hline
\end{tabular}

Note: Generalised linear model with a logit link function; standard errors are clustered by procedure.

$* * \mathrm{p}<0.01 ; * \mathrm{p}<0.05$ 